\title{
Factors Affecting Farmers' Decisions to Use Certified Granola Potato Seeds in Parbuluan District, Dairi Regency
}

\author{
Riama Hotmaina Sinulingga ${ }^{1}$, Iskandarini ${ }^{2}$, Tavi Supriana ${ }^{2}$ \\ ${ }^{1,2}$ Master of Agribusiness Study Program on Faculty of Agriculture of University of Sumatera Utara
}

Corresponding Author: Riama Hotmaina Sinulingga

\begin{abstract}
Agricultural products, including potatoes, are still faced with several problems with fluctuations and quite high price sensitivity, mainly due to changes in demand and supply. Decreased (degenerative) production occurs because of the disease that accumulates in each generation of potato seeds and continues to be carried over to the next generation. So that certified potato seeds are needed to increase farmers' production. This study will analyze the influence of the factors of farmer age, education level, farming experience, productivity, seed price, land area, farmer group participation in influencing farmers' decisions to use certified potato seeds. From the total population of potato farmers as many as 365 farmers in Parbuluan District, Dairi Regency, North Sumatra, testing was carried out on 78 samples with the results that the variables of productivity, price, farmer group participation had a significant effect on the use of certified potato seeds, while the variables of age, education, experience, area Land does not have a significant effect on the use of certified potato seeds and productivity, price, farmer group participation, age, education, experience, and land area all influence farmers' decisions to use certified potato seeds.
\end{abstract}

Keywords: Certified Potato Seed, Potato Farmer, Potato Production

\section{BACKGROUND}

The demand for potatoes in Indonesia continues to increase along with the increasing population, the level of community income and the growth of the potato processing industry (Soegihartono, 2008). Potato commodity is a source of income and job opportunities that contribute quite high to regional economic development. However, agricultural products, including potatoes, are still faced with several problems with fluctuations and quite high price sensitivity, mainly due to changes in demand and supply. During the planting season, farmers experience high prices for certified seeds, while at harvest they face low product prices.

According to data from the Central Statistics Agency for Dairi Regency in 2019 and 2020, Dairi Regency's potato production in 2018 was 3,455 tons, while in 2019 potato production was 2,838 tons, there was a $17.9 \%$ decline in potato production (seventeen point nine percent). Farmers in Parbuluan District almost eighty percent of their income comes from potato cultivation, of course they hope that potato production is high to increase their income. Seed quality and high seed prices are the main obstacles to the development of potato production in developing tropical countries, including Indonesia (Wattimena et al. 1983). The average need for potato seeds per year is 108 thousand tons for a potato cultivation area of 72,000 ha, while the availability of certified potato seeds only reaches 15 percent. The cost of purchasing certified potato seeds for potato cultivation requires 30 percent of the total production costs of potato farming, so farmers set aside part of 
their harvest as local seeds or uncertified seeds for the next planting season.

Decreased (degenerative) production will occur in each generation of potato seeds that are reproduced or planted continuously, this is due to the presence of diseases that accumulate in each generation and continue to be carried over to the next generation, thereby reducing production. So that certified potato seeds are needed to increase farmers' production. This study will analyze the influence of the factors of farmer age, education level, farming experience, productivity, seed price, land area, farmer group participation in influencing farmers' decisions to use certified potato seeds.

\section{Potato Seed Certification}

Certification is based on the results of inspections in the field and in the warehouse by BPSB (Seed Supervision and Certification Center) or the authorized institution. G0 means seeds resulting from disease elimination/eradication, especially systemic diseases, can be in the form of plantlets/plants in vitro, cuttings or mini tubers produced under controlled conditions (in a laboratory or screen house), tolerance for pests and diseases is $0 \%$ with the supervision of the implementing agency. Breeding. G1 means seeds that meet G1 standards or are produced from plantings of G0 or a higher class with supervision from the agency administering Certification and Supervision of Seed Circulation, G2 means seeds that meet G2 standards or are produced from plantings of G1 or a higher class with supervision from the agency organizer of Certification and Supervision of Seed Circulation. Granola variety which is resistant to PVA (Potato Virus A) and PVY (Potato Virus Y), but somewhat sensitive to Pseudomonas solanacearum wilt and Pytophthora infestans late blight. (Pitojo, 2008)

\section{Decision-making}

The concept of a decision support system (Decision Support System / DDS) is known as the "Management decision system". DDS is designed to support all stages of decision-making starting from the stage of identifying problems, selecting relevant data, determining the approach used in the decision-making process to evaluating alternative selection activities. (S. Wa Imri Nur Santi Sutardi, 2015). Suratiyah (2006) farming income and costs are influenced by internal and external factors. Internal factors consist of farmer's age, education, knowledge, experience, skills, number of workers, land area and capital. External factors in the form of prices and the availability of production facilities.

\section{Conceptual framework}

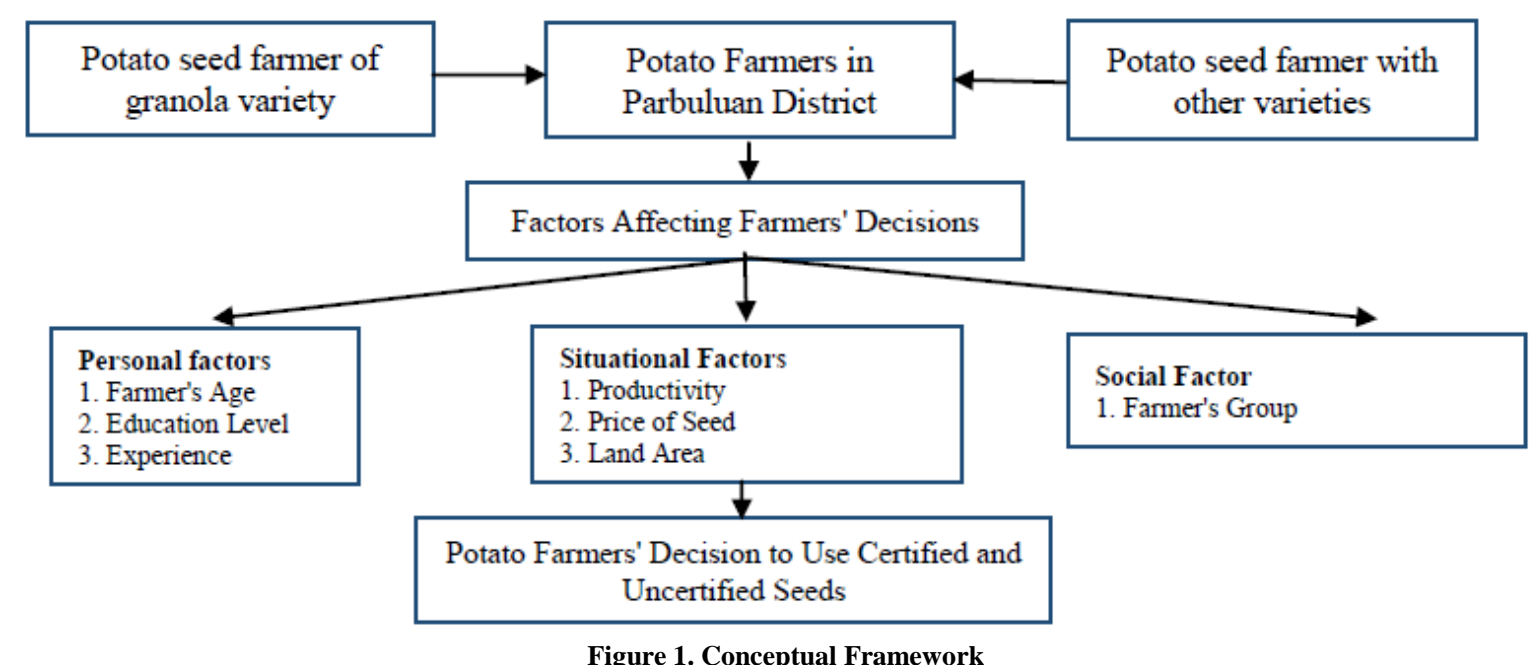




\section{Hypothesis}

Personal factors, namely: farmer's age, farmer's education level, farming experience, situational factors: productivity, seed price, land area, social factors, namely: farmer group participation has a significant positive effect on farmers' decisions to use certified potato seeds in Parbuluan District, Dairi Regency.

Personal factors, namely: farmer's age, farmer's education level, farming experience, situational factors, namely: productivity, seed price, land area, social factors, namely: participation of farmer groups together has a real positive effect on farmers' decisions to use certified potato seeds in Parbuluan District, Dairi Regency.

\section{RESEARCH METHODS}

The location of the research was determined purposively, namely in Parbuluan District, Dairi Regency, North Sumatra. The research location was chosen in Parbuluan District because it is the largest potato production area in Dairi Regency. The population is potato farmers as many as 365 farmers, with a total sample of 78 people. Primary data was collected through interview techniques using structured questionnaires to farmers using certified potato seeds and farmers using non-certified potato seeds. To solve this research problem, it was analyzed using logistic regression model method. Testing the significance of the model and parameters was carried out with the Likelihood Ratio test, Wald's test, and Coefficient Interpretation.

\section{RESULTS AND DISCUSSION Model Feasibility Analysis}

Analysis of the feasibility of the model with the Hosmer and Lemeshow test table shows the value of Sig. $0.615>$ alpha 0.05 which indicates that $\mathrm{HO}$ is rejected. This means that the model is accepted and can be used for further analysis because there is no significant difference between the model and the observed values.

\section{Nagelkerke value $\mathbf{R}$ square}

The value of Nagelkerke $R$ square is used to see the ability of the independent variable in explaining the dependent variable. The Nagelkerke $R$ square value is 0.750 . The independent variable is able to explain 75 percent of the diversity of the logistic regression model, the remaining 25 percent is explained by other variables from the model.

\section{Value -2 log likelihood}

Assessing the entire model can use a value of $-2 \log$ likelihood, where at the beginning (Block number $=0$ ) the value of $2 \log$ likelihood is 108.131 while at (Block Number $=1$ ) the value of $-2 \log$ likelihood is 43.640. This decrease indicates a better regression model.

\section{Significance Test Results}

A variable is declared to have a significant effect if the value of Sig. less than or equal to $\alpha$. The alpha values used in this study were 5 percent and 10 percent. If the value of Sig. smaller than alpha then reject $\mathrm{H} 0$, so that if the value of $\mathrm{Sig}$ is smaller than alpha it will mean that the variable has a significant effect on the model at the alpha level. The value of B or the coefficient on the output of logistic regression shows how the influence of the independent variable on the dependent variable (Y).

The value of $\operatorname{Exp}(\mathrm{B})$ in the logistic regression is the value of the odds ratio. The direction of the effect is positive if the odds ratio is greater than one. The direction of the effect is negative if the odds ratio is between zero (0) and one (1), whereas if the odds ratio is one, it means that the independent variable has no effect on the dependent variable.

Based on table 1, it is known that of the seven independent variables in the table, there are three variables that have a significant effect on the use of certified seeds at the alpha 5 percent level of significance. 
Riama Hotmaina Sinulingga et.al. Factors affecting farmers' decisions to use certified granola potato seeds in Parbuluan District, Dairi Regency.

Table 1. The results of the estimation of the logistic regression model that affect farmers' decisions to use certified seeds.

\begin{tabular}{|l|l|l|l|l|l|l|}
\hline Variable & $\begin{array}{l}\text { B } \\
\text { Lower }\end{array}$ & $\begin{array}{l}\text { S.E } \\
\text { Upper }\end{array}$ & $\begin{array}{l}\text { Wald } \\
\text { Lower }\end{array}$ & $\begin{array}{l}\text { Df } \\
\text { Upper }\end{array}$ & $\begin{array}{l}\text { Sig } \\
\text { Lower }\end{array}$ & $\begin{array}{l}\text { Exp (B) } \\
\text { Upper }\end{array}$ \\
\hline Age & -0.014 & 0.072 & 0.035 & 1 & 0.851 & 0.987 \\
\hline Education & 0.192 & 0.173 & 1.228 & 1 & 0.268 & 1.211 \\
\hline Experience & 0.045 & 0.088 & 0.266 & 1 & 0.606 & 1.046 \\
\hline Productivity & 0.203 & 0.092 & 4.875 & 1 & $* * 0.027$ & 1.225 \\
\hline Price & 0.000 & 0.000 & 7.082 & 1 & $* * 0.008$ & 1.000 \\
\hline Land area & -1.381 & 1.078 & 1.640 & 1 & 0.200 & 0.251 \\
\hline Opt-in & 2.798 & 1.355 & 4.264 & 1 & $* * 0.039$ & 16.416 \\
\hline Constant & -10.049 & 3.845 & 6.829 & 1 & 0.009 & 0.000 \\
\hline \multicolumn{7}{|c|}{ Description: ** significant at level $=5 \%$} \\
\end{tabular}

\section{Certified Potato Seed Productivity}

Productivity variables in certified potato seeds in the study had a significant positive effect because they had a Sig value. by 0.027 at 5 percent alpha. The productivity variable has an odds ratio of 1,225 , which means that if the productivity increases by 1 time, the farmer's opportunity to use certified potato seeds is 1,225 times. This is in accordance with research conducted by Rr. Myristica Ayu Apriliana and Moch. Muslich Mustadjab (2016), stated that hybrid corn has a higher average production per hectare, almost 41.5 percent higher than the average production of nonhybrid corn plants. Logically, potato farming from certified seeds produces high productivity, it will provide high profits to farmers.

\section{Certified Potato Seed Price}

The seed price variable has a value of Sig. of 0.008 , this variable has a significant effect on the use of certified potato seeds, the odds ratio is 1,000 , meaning that if there is an increase in the price of certified seeds of 1 rupiah, the farmer's opportunity to use certified potato seeds is 1.0 , the condition of cateris paribus. This is contrary to Sayaka and Hestina (2011) who stated that one of the factors that influence farmers' decisions to use certified seeds is the price of seeds. The high price of certified seeds makes farmers unable to buy certified seeds. The factor of seed prices does not discourage farmers who own capital from using certified potato seeds, for reasons of high productivity produced from certified potato seeds, farmers still choose certified potato seeds.

\section{Farmer Group Participation}

The farmer group participation variable has a value of Sig. of 0.039 this variable has a significant effect on the use of certified potato seeds. This is in accordance with the research of Elvira Iskandar and Hatipal Nurtilawati (2019), the factor that significantly influences the level of perception is the social interaction of farmers, which is reflected by the interaction of farmers with extension workers on the application of Integrated Crop Management (PTT) which is an innovative approach that seeks to increase farm productivity and maintain the sustainability of land use for farming.

\section{Potato Farmer Age}

The respondent's age variable has a Sig value. of 0.851 this variable had no significant effect on the use of certified potato seeds and had a negative effect. The age variable has an odds ratio of 0.987 , which means that if the age of the farmer increases by one year, the farmer's opportunity to use certified seed is 0.987 , which is smaller than the original condition, cateris paribus. This is not in accordance with the theory of Soekartawi (2005) which states that the younger the age of the farmer, the more eager to know, so they will try to adopt agricultural innovations.

\section{Potato Farmer Education}

The respondent's education variable has a value of Sig. of 0.268 this variable has no significant effect on the use of certified potato seeds, this is contrary to the opinion of Soekartawi (2005) if someone who has higher education is relatively faster in implementing innovation adoption quickly. 
Potato farmers in Parbuluan Sub-district are dominated by an elementary school education level of around 43.59 percent who use uncertified potato seeds.

\section{Potato Farmer Experience}

The respondent's experience variable has a value of Sig. of 0.606 this variable has no significant effect on the use of certified potato seeds. This is contrary to the research of Aditya Dhanu Prasetya and Lasmono Tri Sunaryanto (2019) from the results of their research the experience of farmers using certified seeds in the previous profitable planting season, will return to using certified rice seeds in the next planting.

\section{Potato Planted Area}

The respondent's potato crop area variable has a Sig value. of 0.606 this variable has no significant effect on the use of certified potato seeds. This is contrary to research conducted by Utami and Suminah (2005) that land area has a positive influence on the use of BBBA melon seeds (Certified Seeds). Farmers who use certified potato seeds are dominated by farmers who have land smaller than 0.85 ha as much as 51.28 percent, this shows that farmers will spend a large amount of capital for land larger than 0.85 ha, farmers are constrained by capital for the purchase of certified potato seeds.

\section{CONCLUSION}

The variables of productivity, price, farmer group participation have a significant effect on the use of certified potato seeds, while the variables of age, education, experience, land area have no significant effect on the use of certified potato seeds.

Productivity, price, farmer group participation, age, education, experience, and land area all influence farmers' decisions to use certified potato seeds.

\section{Acknowledgement: None}

Conflict of Interest: None

\section{Source of Funding: None}

\section{REFERENCES}

1. Badan Pusat Statistik Kabupaten Dairi, 2020, Kabupaten Dairi Dalam Angka 2020, Sidikalang.

2. Badan Pusat Statistik Provinsi Sumatera Utara, Provinsi Sumatera Utara Dalam Angka, 2020, Medan.

3. Balitsa (Balai Penelitian Sayuran) 2015 Pemilihan Benih Kentang Harus Memenuhi Syarat. Tersedia pada http:// balitsa. Litbang.

Pertanian.go.id/ind/index.php/berita terbaru/380.

4. Bishop T. 1989. Pengantar Analisis Ekonomi Pertanian. Jakarta (ID): Mutiara.

5. Chipande GHR. 1987. Innovation Adoption among Female Headed Households:the Case of Malawi. Economic Development and Cultural Change. 18: 315-327.

6. Crissman C, Hibon A. 1996. Establishing Seed Potato Prices: Concepts, Procedures and Implications for Research and Training. Social Science Department. Working Paper. CIP. Lima Peru.

7. Harini R. 2003. Tingkat Efisiensi Perubahan Usahatani Padi di Kecamatan Seyegan. Majalah Geografi Indonesia 17(2): 81-94.

8. Hosmer, D.W. dan S. Lemeshow. 1989 Applied Logistik Regresion, Second Edition John Wiley \& Sons, Inc. New York.

9. Joni, M.MA, M.F.R Rubzen, and P.J. Batt. 2001. 1Factors inflencing a farmer's decision to purchase seed potatoes in East Java. Paper presented at the 45th Annual Conferance of the Australian and Resource Economics Society, adelaide, South Australia.

10. Kotler, Philips and Gary Armstrong, 2008 Prinsip-Prinsip Pemasaran Edisi 12 Jilid I, Erlangga Jakarta.

11. Pitojo, Sutijo, 2008 Penangkaran Benih Kentang, Kanisius, Jogjakarta.

12. Ruskandar, A. 2006. Varietas Unggul Baru Padi yang Banyak Ditunggu Petani. (http://pustaka.litbang.deptan.go.id/bppi/len gkap/st260706-1.pdf).

13. Santosos, S. 2017. Statistik Multivariant dengan SPSS. Elex Media Koputindo, Jakarta. 
Riama Hotmaina Sinulingga et.al. Factors affecting farmers' decisions to use certified granola potato seeds in Parbuluan District, Dairi Regency.

14. Sayaka, B. Hestina J, 2011 Kendala Adopsi Benih Bersertifikat untuk Usahatani Kentang, jurnal Pusat Sosial Ekonomi dan Kebijakan Bisnis Vol. 29 No.1.

15. Setiadi, 2009, Budidaya Kentang, Penebar Swadaya, Jakarta.

16. Shinta, Agustina (2011). Ilmu Usahatani, Penerbit Universias Brawijaya Press, Malang.

17. Soekartawi, 2002. Faktor - faktor produksi. Salemba Empat. Jakarta

18. Soedarso, Sri Widodo. 2017 Teori dan Teknik Pengambilan Keputusan. Percetakan Manggu Makmur Tanjung Lestari. Bandung.

19. Suratiyah, K. 2008. Ilmu Usahatani Cet-2. Penebar Swadaya, Jakarrta
20. Suwarno WB. 2000. Sistem perbenihan kentang di Indonesia. Tersedia pada https://situshijau.co.id

21. Wattimena, G. Mc. Cown, B \& Weis, G. 1983, Comparative field performance of potatoes from micro-culture', Amer. Potato J., Vol. 60. No. 1, pp 27-33

How to cite this article: Sinulingga RH, Iskandarini, Supriana T. Factors affecting farmers' decisions to use certified granola potato seeds in Parbuluan District, Dairi Regency. International Journal of Research and Review. 2021; 8(8): 121-126. DOI: https://doi.org/10. 52403/ijrr.20210818 